American Journal of Agricultural and Biological Sciences 5 (2): 169-176, 2010

ISSN 1557-4989

(C) 2010 Science Publications

\title{
Evaluation of Hairy Vetch (Vicia villosa Roth) in Pure and Mixed Cropping with Barley (Hordeum vulgare L.) to Determine the Best Combination of Legume and Cereal for Forage Production
}

\author{
${ }^{1}$ Seyedeh, ${ }^{1}$ Davood Habibi, ${ }^{1}$ Ali Kashani, ${ }^{2}$ Farzad Paknejad, \\ ${ }^{3}$ Hossein Jafary, ${ }^{4}$ Majid Jami Al-Ahmadi, ${ }^{5}$ Mohamad Reza Tookalloo and ${ }^{6}$ Javad Lamei \\ ${ }^{1}$ Department of Agronomy, Islamic Azad University, Karaj Branch, Iran \\ ${ }^{2}$ Department of Agronomy, Agriculture Research Center, Islamic Azad University, Karaj Branch, Iran \\ ${ }^{3}$ Section of Plant Protection, Agriculture and Natural Resources Research Center of Zanjan, Iran \\ ${ }^{4}$ Department of Agronomy and Plant Breeding, Faculty of Agriculture, \\ The University of Birjand, P.O. Box 97175-331, Birjand, Iran \\ ${ }^{5}$ Department of Agronomy, Islamic Azad University, Bojnord Branch, Iran \\ ${ }^{6}$ Section of Agronomy, Agriculture and Natural Resources Research Center, Zanjan, Iran
}

\begin{abstract}
Problem statement: Mixed cereal-legume cropping can supply valuable forage in dry areas, as well as improving soil characteristics to approach sustainable farming systems in these regions. Approach: In order to comprise quality and quantity of produced forage and to determine the best planting ratio in a hairy vetch and barley mix cropping, a two year study was conducted during 2008 and 2009 in Zanjan Center for Research of Agricultural Science and Natural Resources, Zanjan, Iran, using these two forage crops in a completely randomized block design with five treatments and four replications. Hairy vetch and barley were single- or mix cropped at 100:0, 75:25, 50:50, 25:75 and 0:100 ratios. Results: Analysis of variance of two years data showed hay yield, absorbed N, P and K amounts and crude protein content varied among years and different planting ratio, significantly, with higher amounts in the second year. The highest dry matter yield, absorbed $\mathrm{N}, \mathrm{P}$ and $\mathrm{K}$ and crude protein content were obtained in 50:50 planting ratio. The land equivalent ratio was more than one for all mix cropping treatments, with the highest value in 50:50 planting ratio, which also led to the highest LER in respect to crude protein. Conclusion: A 50:50 mixture of barley-hairy vetch can produce the highest dry forage yield, with a higher LER and the highest forage quality than sole cropping.
\end{abstract}

Key words: Crude protein, land equivalent ratio, planting ratio, replacement series

\section{INTRODUCTION}

The objects of intercropping, as a type of sustainable systems in agriculture, are making ecological equilibrium (increasing biodiversity), more resources exploitation, improving yield quantitatively and qualitatively and to relieve damages caused by pests, diseases and weeds. Since posing environment protection, the intercropping has been expanding (Beets, 1982).

Nowadays, the management methods are improving in some agricultural systems in order to reduce agrochemical consumption, to compensate increasing production costs, to reduce impacts of chemicals on environments and to conserve soil fertility. Herein, expanding fodder crops cultivation has suggested as an alternative approach to synthetical fertilizers (Franzluebbers, 2007; Kirschenmann, 2007).

Hairy vetch is an annual leguminous crop which produces high-quality forage and can be cultivated in most climates as rainfed or irrigated, but grows best in temperate and cold-temperate conditions. In recent years, vetch and grass pea cultivation has drawn many attentions as a crop well-adapted to harsh conditions and arid and semi-arid regions, with high protein content (Campbell, 1997). The different Vicia species are used as direct grazing and also for their green forage, hay and seed (Lanyasunya et al., 2007). The

Corresponding Author: Majid Jami Al-Ahmadi, Department of Agronomy and Plant Breeding, Faculty of Agriculture, The University of Birjand, P.O. Box 97175-331, Birjand, Iran Tel: +98 $5612254041 /+989155098836$ Fax: +98 5612254050 
nutritional value of all Vicia species at the first flowering stage is comparable with most forage crops and their fresh forage contain a high protein percentage (16.5-26.5\%) (Arsalan and Kurdali, 1996). Gohl (1981) stated that a freshly harvested forage of hairy vetch have 17\% Dry Matter (DM), 23\% Crude Protein (CP), $29 \%$ Crude Fiber (CF), with 81 and 53\% digestibility for $\mathrm{CP}$ and $\mathrm{CF}$, respectively. In studies of Pinkerton and Pinkerton (2002) and Lanyasunya et al. (2007), the CP, $\mathrm{Ca}$ and $\mathrm{P}$ contents of common vetch (Vicia sativa $\mathrm{L}$.) has shown to be $18.4,0.132$ and $0.34 \%$ on a dry weight basis, respectively, with $59 \%$ total digestible nutrients.

Introducing forage crops in rotations of cerealmonoculture based agrecosystems can confer many advantages. Sowing a forage crop in rotation with cereals is a highly effective method for, for example, soil properties reclamation (MeVay et al., 1989) and increasing rainwater infiltration in soils (Daniel et al., 2006). The high ability of forage legumes for nitrogen fixation is among their most important characters that can reduce needs for applying chemical nitrogen fertilizers with implementing them in farming rotations (Rao et al., 2005). Karadag (2004) stated expanding cultivation of annual forage legumes in arid and semiarid regions in Turkey may be a proper alternative for fallow in rainfed conditions and can play a significant role to compensate a part of forage deficiency in these areas. The optimal exploitation of available natural resources, producing a high quality forage rich in protein for animal feeding, soil fertility improvement, enhancing land productivity and production stability are among the most important benefits of legume-cereal mixtures compared to their monocultures.

In recent years, a special attention has been paid to hairy vetch cultivation as a annual winter forage crop in upland farming and putting it in rotation with rice in Japan to compensate nitrogen deficiency, due to its high nitrogen fixation capacity (Zougmore et al., 2006). In a technical and economic evaluation of planting common vetch, cumin and sunflower in rotation with barley under rainfed condition, Yau et al. (2004) found the higher biological yield and net income of the vetchbarley rotation in the Bekaa Valley of Lebanon in comparison with planting barley as monoculture or in rotation with cumin and/or sunflower.

Clearly, one the most important reason for planting two or more crops together is increasing production per area (Ghosh, 2004). Land Equivalent Ratio (LER) is used by researchers as an indicator to assess effect of intercropping on land productivity (Mead and Willey, 1980). This criterion indicates how much area under sole cropping is needed to obtain equal amounts of yield from one hectare of intercropped area. In the other words, it defines the sum of the fractions of the intercropped yields divided by the sole-crop yields. Weil (1988) reported that hay yield obtained from a mixture of alfalfa with some grasses was higher than their sole cropping. Prasad et al. (1990) stated crosssowing of deenanath grass (Pennisetum pedicellatum) with cowpea (Vigna unguiculata) at 12 and $40 \mathrm{~kg}$ seeds $\mathrm{ha}^{-1}$, respectively, gave the highest fresh fodder, $\mathrm{DM}$ and $\mathrm{CP}$ yields and net returns, with the highest land equivalent ratio (1.52), than other sowing methods. Intercropping of vetch-barley in Syria for forage production also led to higher land productivity (Arsalan and Kurdali, 1996).

Concerning forage shortage in dry areas of Iran, our purpose was to evaluate vetch-barley mixed system to find the best combination of these crops in mixture in respect to LER and quality and quantity of produced forage.

\section{MATERIALS AND METHODS}

This two-year study was conducted during 2008 and 2009 growth seasons in KheirAbad Research Station, Zanjan Center for Research of Agricultural Science and Natural Resources, Zanjan, Iran $\left(48^{\circ} 47^{\prime} \mathrm{E}, 36^{\circ} 31^{\prime} \mathrm{N}, 1770 \mathrm{~m}\right)$. The barley (cv. Sahand) and hairy vetch were mixed sown in a replacement series experiment based on randomized complete block design with five treatments and four replications. Two crops were sown each as sole cropping and also were mix cropped at 75:25, 50:50 and 25:75 ratios. The plant densities for pure stands were 350 and $250 \mathrm{pl} \mathrm{m}^{-1}$ for barley and vetch, respectively. Each plot was $3 \mathrm{~m}$ in width and $5 \mathrm{~m}$ in length. All plots were hand-seeded at 19 Nov. Based on soil analysis (Table 1), $46 \mathrm{~kg} \mathrm{P}_{2} \mathrm{O}_{5} \mathrm{ha}^{-1}$ before planting and $23 \mathrm{~kg} \mathrm{~N} \mathrm{ha}^{-1}$ at 3 and 9 May in 2008 and 2009, respectively, were applied. The first irrigation was done in 15 April, when frosty season was terminated and continued till harvest time, based on crops requirement. Crops soilage was harvested at $50 \%$ flowering of hairy vetch, when barley kernels were at early doughy stage (Mid June).

To determine fresh and dry forage yields, all plants in two $\mathrm{m}^{2}$ of each plots were harvested from ground surface, two crops were separated and weighted immediately for fresh yield. A $500 \mathrm{~g}$ sample was separated from both crops of each plot and putted in $70^{\circ} \mathrm{C}$ oven for $48 \mathrm{~h}$ and then again weighted to calculate moisture content of samples, which was used to determine dry yield. 
Am. J. Agri. \& Biol. Sci., 5 (2): 169-176, 2010

Table 1: Results of soil analysis of experimental plots in Zanjan. In each year, samples were taken from 0-30 and 30-60 cm depth separately

\begin{tabular}{|c|c|c|c|c|c|c|c|c|c|c|c|}
\hline \multirow[b]{2}{*}{ Year } & \multirow{2}{*}{$\begin{array}{l}\text { Depth } \\
\text { (cm) }\end{array}$} & \multirow{2}{*}{$\begin{array}{l}\text { Saturation } \\
(\%)\end{array}$} & \multirow{2}{*}{$\begin{array}{l}\text { EC } \\
\left(\mathrm{ds} \mathrm{m}^{-1}\right)\end{array}$} & \multirow[t]{2}{*}{$\mathrm{pH}$} & $\mathrm{OC}$ & $\mathrm{P}$ & $\mathrm{K}$ & \multirow[t]{2}{*}{ Clay } & Sand & Silt & \multirow[b]{2}{*}{ Texture } \\
\hline & & & & & ----- & $\mathrm{pm}-$ & ----- & & --ppm & ----- & \\
\hline \multirow[t]{2}{*}{2008} & $0-30$ & 41.0 & 0.68 & 7.87 & 0.66 & 11.4 & 400 & 36 & 30 & 34 & Clay-loam \\
\hline & $30-60$ & 46.0 & 0.48 & 7.91 & 0.49 & 3.2 & 234 & 46 & 24 & 30 & Clay \\
\hline \multirow[t]{2}{*}{2009} & $0-30$ & 41.7 & 0.87 & 7.8 & 0.69 & 12.6 & 506 & 30 & 32 & 38 & Clay-loam \\
\hline & $30-60$ & 42.8 & 0.70 & 7.9 & 0.64 & 4.0 & 278 & 42 & 26 & 32 & Clay \\
\hline
\end{tabular}

A subsample of dried plot samples was grinded and used for quality tests. Nitrogen content was determined as Kjeldhal method (Kjeltec Auto 1030 Analyzer) and then crude protein yield was calculated. The phosphorus was measured as calorimetric method using spectrophotometer and potash was determined using flame photometry (Walling et al., 1989).

The measure used to estimate effectiveness and profitability of inter-or mixed cropping is Land Equivalent Ratio (LER), which is calculated as (Mead and Willey, 1980):

$\operatorname{LER}=\mathrm{Y}_{\mathrm{ij}} / \mathrm{Y}_{\mathrm{ii}}+\mathrm{Y}_{\mathrm{ji}} / \mathrm{Y}_{\mathrm{jj}}$

Where:

$\mathrm{Y}_{\mathrm{ii}}$ and $\mathrm{Y}_{\mathrm{jj}}=$ Yields of $\mathrm{i}$ and $\mathrm{j}$ species in their sole cropping

$Y_{\mathrm{ij}}$ and $\mathrm{Y}_{\mathrm{ji}}=$ Their yield in mixed cropping

When LER measures 1.0, it indicates that the mixed cropping and sole cropping have yield equivalence, LERs above 1.0 indicate advantages of mixed cropping and LERs below 1.0 show no real yield advantages from mixed cropping. The predicted yields for each two crops were calculated as product of its ratio in mixture multiply in sole crop yield and then were added to obtain the estimated yield for whole mix cropping.

Data analysis for two years was done using SAS. Analysis of combined experiments was done at the end of two years and means were compared using Duncan's multiple range test at 0.05 probability level. Before statistical analysis, all data were passed normality test and were transformed were needed. All graphs were drawn with Excel.

\section{RESULTS}

Forage yield and quality: Based on combined analysis of data, there were significant differences between years and planting ratios regarding dry forage yield, absorbed N, P, K and crude protein in mixed vetchbarley (Table 2), all were higher in the second years, significantly (Table 3 ). This may be due to moderate temperatures and more uniform distribution of annual participation during 2008-2009 than first year (Fig. 1).

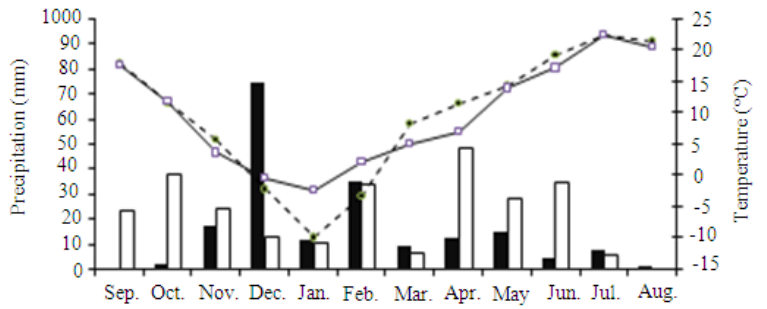

Fig. 1:Two years monthly weather data of experimental site, KheirAbad, Zanjan, Iran. Bars show precipitation during 2007-2008 (dark) and 20082009 (white). Lines represent monthly average temperature for 2007-2008 (--•--) and 2008$2009(-\square-)$

In average of two years, dry forage yield showed significant difference between planting ratios. The highest yield was obtained with 50:50 hairy vetchbarley ratio and sole cropping of vetch produced the lowest yield, with any difference between 75:25, 25:75 and 0:100 vetch-barley ratios (Table 3). The highest increase in yields of second year was obtained with $25: 75$ vetch-barley ratio (18.93\%) and pure stand of vetch with only $4.20 \%$ more yield, took least advantage of more favorable conditions in second years (Table 4).

Evaluation of dry forage yield and crude protein content using LER: the LERs in all mixed treatments were more than one (Table 5). The highest LERs in respect of dry forage production in 1st and 2 nd years (1.34 and 1.38, respectively) were obtained with mixed cropping hairy vetch and barley in 50:50 planting ratio, which means 34 and $38 \%$ more land were needed in sole cropping in 2007-2008 and 2008-2009, respectively, to produce a dry soilage yield similar to 50:50 mixture (Table 5). For crude protein yield, the 50:50 planting ratio had the highest LERs in both years (Table 5). In the other hand, 49 and 54\% more crude protein in the first and second years, respectively, were produced in this treatment than sole cropping. The lowest yield-LER and protein-LER was belonged to 25:75 vetch-barley ratio (Table 5).

To assess better the mixed cropping profitability, replacement series curves for expected and actual forage yields of mixture components was drawn (Fig. 2). 
Am. J. Agri. \& Biol. Sci., 5 (2): 169-176, 2010

Table 2: Analysis of variance for combined experiments, conducted during two successive growth seasons of 2007-2008 and 2008-2009. In both years, hairy vetch and barley were sown as pure or mixed cropping in a replacement series with 100:0, 25:75, 50:50; 75:25 and 100:0 planting ratio in KheirAbad Research Station, Zanjan, Iran

\begin{tabular}{|c|c|c|c|c|c|c|}
\hline \multirow[b]{2}{*}{ Source of variance } & \multirow[b]{2}{*}{$\mathrm{df}$} & \multicolumn{5}{|l|}{ Mean squares } \\
\hline & & Dry forage yield & $\mathrm{N}$ & $\mathrm{P}$ & $\mathrm{K}$ & Protein \\
\hline Year & 1 & $4.111^{*}$ & $4.311^{*}$ & $143.058^{* *}$ & $32505.960^{* *}$ & $4.1150^{* *}$ \\
\hline Error & 6 & 0.458 & 0.372 & 7.745 & 824.774 & 0.4400 \\
\hline Treat & 4 & $6.418^{* *}$ & $6.649^{* *}$ & $115.539^{* *}$ & $15924.008^{* *}$ & $6.6000^{* *}$ \\
\hline Year $\times$ Treat & 4 & $0.159^{\text {ns }}$ & $0.134^{\text {ns }}$ & $0.695^{\mathrm{ns}}$ & $263.978^{\mathrm{ns}}$ & $0.1450^{\text {ns }}$ \\
\hline Error & 24 & 0.172 & 0.151 & 2.939 & 278.594 & 0.1480 \\
\hline $\mathrm{CV}$ & & 13.836 & 12.954 & 9.410 & 9.353 & 12.8570 \\
\hline
\end{tabular}

Table 3: Means comparison for two-year combined data of dry forage yield, total absorbed N, P and K, and protein yield of different hairy vetchbarley ratios in mixed cropping and in two years of study

\begin{tabular}{|c|c|c|c|c|c|}
\hline \multirow[b]{2}{*}{ Treatments } & \multirow{2}{*}{$\begin{array}{l}\text { Dry yield } \\
\left(\text { ton } \mathrm{ha}^{-1} \text { ) }\right. \\
\end{array}$} & \multirow[t]{2}{*}{$\mathrm{N}$} & \multirow{2}{*}{$\begin{array}{c}\mathrm{P} \\
\mathrm{kg} \mathrm{h}\end{array}$} & \multirow{2}{*}{$\mathrm{K}$} & \multirow[b]{2}{*}{ Protein yield } \\
\hline & & & & & \\
\hline \multicolumn{6}{|l|}{ Year } \\
\hline 2007-2008 & $7.251^{\mathrm{b}}$ & $179.921^{\mathrm{b}}$ & $16.322^{\mathrm{b}}$ & $149.947^{\mathrm{b}}$ & $1097.01^{\mathrm{b}}$ \\
\hline 2008-2009 & $8.160^{\mathrm{a}}$ & $211.487^{\mathrm{a}}$ & $20.105^{\mathrm{a}}$ & $206.961^{\mathrm{a}}$ & $1287.36^{\mathrm{a}}$ \\
\hline \multicolumn{6}{|c|}{ Planting ratio (vetch-barley) } \\
\hline 100:0 & $6.018^{\mathrm{c}}$ & $229.883^{b}$ & $19.347^{\mathrm{c}}$ & $195.547^{\mathrm{b}}$ & $1436.77^{a}$ \\
\hline $75: 25$ & $7.471^{\mathrm{b}}$ & $237.259^{\mathrm{ab}}$ & $20.865^{\mathrm{b}}$ & $209.870^{\mathrm{ab}}$ & $1460.35^{\mathrm{a}}$ \\
\hline $50: 50$ & $9.228^{\mathrm{a}}$ & $247.181^{\mathrm{a}}$ & $22.255^{\mathrm{a}}$ & $222.329^{\mathrm{a}}$ & $1504.03^{\mathrm{a}}$ \\
\hline $25: 75$ & $8.162^{b}$ & $151.149^{\mathrm{c}}$ & $15.416^{\mathrm{d}}$ & $147.920^{\mathrm{c}}$ & $900.60^{\mathrm{b}}$ \\
\hline $0: 100$ & $7.648^{\mathrm{b}}$ & $113.049^{\mathrm{d}}$ & $13.185^{\mathrm{e}}$ & $116.603^{d}$ & $659.08^{c}$ \\
\hline
\end{tabular}

Note: In each columns and for each treatment (year and planting ratio), means with one similar letter do not differ significantly

Table 4: Means comparison of dry forage yield, total absorbed N, P and K, and protein yield of different hairy vetch-barley ratios in mixed cropping. Data are analyzed and compared separately for each year

\begin{tabular}{|c|c|c|c|c|c|c|}
\hline Year & $\begin{array}{l}\text { Planting ratio } \\
\text { (vetch-barley) }\end{array}$ & $\begin{array}{l}\text { Dry forage } \\
\text { yield (ton ha }{ }^{-1} \text { ) }\end{array}$ & $\begin{array}{l}\mathrm{N} \\
-----\end{array}$ & $\begin{array}{l}\mathrm{P} \\
-\mathrm{kg} \mathrm{ha}^{-1}-\end{array}$ & $\mathrm{K}$ & Protein yield \\
\hline \multirow[t]{5}{*}{$2007-2008$} & $100: 0$ & $5.90^{\mathrm{c}}$ & $218.28^{\mathrm{a}}$ & $17.809^{\mathrm{b}}$ & $171.89^{\mathrm{a}}$ & $1364.25^{\mathrm{a}}$ \\
\hline & $75: 25$ & $7.09^{\mathrm{b}}$ & $218.72^{\mathrm{a}}$ & $18.524^{\mathrm{ab}}$ & $177.46^{\mathrm{a}}$ & $1344.96^{\mathrm{a}}$ \\
\hline & $50: 50$ & $8.68^{\mathrm{a}}$ & $228.31^{\mathrm{a}}$ & $20.348^{\mathrm{a}}$ & $189.27^{\mathrm{a}}$ & $1391.08^{\mathrm{a}}$ \\
\hline & $25: 75$ & $7.45^{\mathrm{b}}$ & $132.25^{\mathrm{b}}$ & $13.500^{\mathrm{c}}$ & $115.47^{\mathrm{b}}$ & $789.80^{\mathrm{b}}$ \\
\hline & $0: 100$ & $7.11^{\mathrm{b}}$ & $102.05^{\mathrm{c}}$ & $11.430^{\mathrm{d}}$ & $95.64^{\mathrm{c}}$ & $594.97^{\mathrm{c}}$ \\
\hline \multirow[t]{5}{*}{ 2008-2009 } & 100:0 & $6.14^{\mathrm{d}}$ & $241.48^{\mathrm{a}}$ & $20.884^{b}$ & $219.20^{\mathrm{b}}$ & $1509.28^{\mathrm{a}}$ \\
\hline & $75: 25$ & $7.84^{\mathrm{bc}}$ & $255.80^{\mathrm{a}}$ & $23.207^{\mathrm{ab}}$ & $242.28^{\mathrm{ab}}$ & $1575.74^{\mathrm{a}}$ \\
\hline & $50: 50$ & $9.77^{\mathrm{a}}$ & $266.05^{\mathrm{a}}$ & $24.163^{\mathrm{a}}$ & $255.39^{\mathrm{a}}$ & $1617.80^{\mathrm{a}}$ \\
\hline & $25: 75$ & $8.87^{\mathrm{ab}}$ & $170.05^{\mathrm{b}}$ & $17.332^{\mathrm{c}}$ & $180.37^{\mathrm{c}}$ & $1011.40^{\mathrm{b}}$ \\
\hline & $0: 100$ & $8.18^{\mathrm{bc}}$ & $124.05^{\mathrm{c}}$ & $14.939^{c}$ & $137.56^{\mathrm{d}}$ & $723.19^{c}$ \\
\hline
\end{tabular}

In each column and for each year, means with one similar letter do not differ significantly

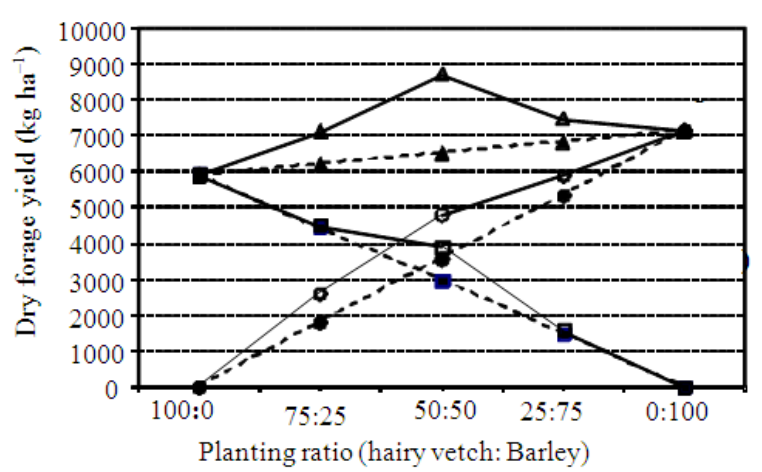

(a)

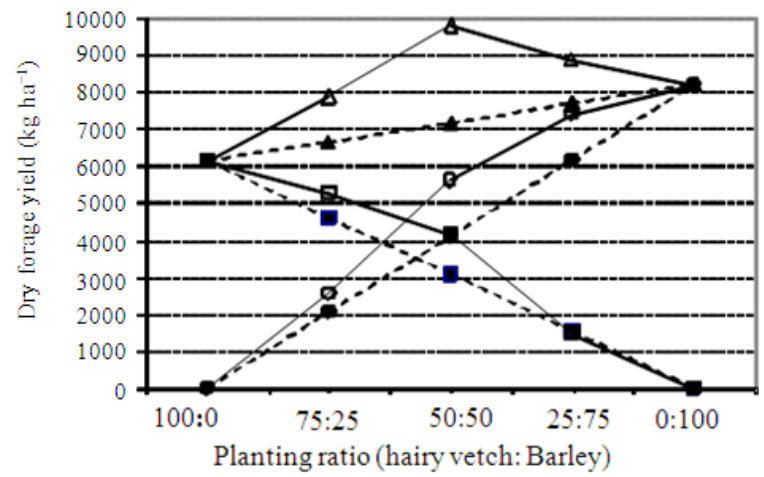

(b)

Fig. 2: Replacement series diagrams with expected (fill symbols, dashed lines) and observed (empty symbols, solid lines) total dry forage of hairy vetch (squares), barley (circles) and their whole mixed cropping (triangles) in experiments of (a) 2007-2008 and (b) 2008-2009 growth seasons 
Am. J. Agri. \& Biol. Sci., 5 (2): 169-176, 2010

Table 5: Land equivalent ratio (LER) for different proportion of hairy vetch and barley in a mixed cropping during two successive years. LERs were calculated for both forage dry yield (LER-Yield) and protein yield (LER-Protein)

\begin{tabular}{|c|c|c|c|c|}
\hline \multirow[b]{2}{*}{ Planting ratio (Vetch:Barley) } & \multicolumn{2}{|l|}{ LER-yield } & \multicolumn{2}{|l|}{ LER-protein } \\
\hline & $2007-2008$ & 2008-2009 & $2007-2008$ & $2008-2009$ \\
\hline $75: 25$ & $1.14^{\mathrm{b}}$ & $1.19^{\mathrm{b}}$ & $1.28^{\mathrm{b}}$ & $1.28^{\mathrm{b}}$ \\
\hline $50: 50$ & $1.34^{\mathrm{a}}$ & $1.38^{\mathrm{a}}$ & $1.49^{\mathrm{a}}$ & $1.54^{\mathrm{a}}$ \\
\hline $25: 75$ & $1.10^{\mathrm{b}}$ & $1.16^{\mathrm{b}}$ & $1.06^{\mathrm{c}}$ & $1.19^{\mathrm{b}}$ \\
\hline
\end{tabular}

Note: In each column and for each year, means with one similar letter do not differ significantly

Table 6: The predicted and observed dry forage yield of hairy vetch and barley planted as sole cropping and/or mixed cropping with different proportion during two successive years

\begin{tabular}{|c|c|c|c|c|c|c|}
\hline \multirow[b]{2}{*}{$\begin{array}{l}\text { Planting ratio } \\
\text { (Vetch:Barley) }\end{array}$} & \multicolumn{2}{|c|}{ Hairy vetch } & \multicolumn{2}{|l|}{ Barley } & \multicolumn{2}{|l|}{ Mixture } \\
\hline & Predicted & Observed & Predicted & Observed & Predicted & Observed \\
\hline \multicolumn{7}{|l|}{$2007-2008$} \\
\hline 100:0 & 5894.85 & 5894.85 & 0.00 & 0.00 & 5894.85 & 5894.85 \\
\hline $75: 25$ & 4421.14 & 4487.81 & 1779.49 & 2611.71 & 6200.62 & 7099.51 \\
\hline 50:50 & 2947.43 & 3891.06 & 3558.97 & 4795.47 & 6506.40 & 8686.53 \\
\hline $25: 75$ & 1473.71 & 1573.86 & 5338.46 & 5882.98 & 6812.17 & 7456.84 \\
\hline $0: 100$ & 0.00 & 0.00 & 7117.95 & 7117.95 & 7117.95 & 7117.95 \\
\hline \multicolumn{7}{|l|}{ 2008-2009 } \\
\hline 100:0 & 6142.49 & 6142.49 & 0.00 & 0.00 & 6142.49 & 6142.49 \\
\hline $75: 25$ & 4606.87 & 5283.23 & 2044.60 & 2560.74 & 6651.47 & 7843.97 \\
\hline $50: 50$ & 3071.25 & 4150.18 & 4089.20 & 5619.90 & 7160.45 & 9770.08 \\
\hline $25: 75$ & 1535.62 & 1475.53 & 6133.81 & 7392.89 & 7669.43 & 8868.42 \\
\hline $0: 100$ & 0.00 & 0.00 & 8178.41 & 8178.41 & 8178.41 & 8178.41 \\
\hline
\end{tabular}

As illustrated in Fig. 2, for all planting ratios of hairy vetch-barley, actual yield of each crop in all mixed ratios was higher than expected yields. As it can be observed, the more favorable condition in the second year led to a higher increase in actual than predicted yield (Fig. 2, Table 6).

\section{DISCUSSION}

Forage yield and quality: In general, all mixes absorbed more N, P and $\mathrm{K}$ in both years than pure cultures (Table 4), which is an indicative of a synergetic interaction between two crops, when are sown together, leading to exploitation more resource.

The superior planting ratio regarding absorbed $\mathrm{P}$ and $\mathrm{K}$ was 50:50 ratio of vetch-barley, which also produced the highest crude protein (Table 3 and 4). According to Reddy and Willey (1981), LER amounts for total absorbed $\mathrm{N}, \mathrm{P}$ and $\mathrm{K}$ in a pearl milletgroundnut intercropping were $1.25,1.28$ and 1.26, respectively, which indicate higher yields in mixture are related to more nutrient absorption. Increasing barley ratio in mixture caused more $\mathrm{P}$ and $\mathrm{K}$ to be absorbed in second year relative to first year; however, in both years, vetch pure stand absorbed more total $\mathrm{P}$ and $\mathrm{K}$ than pure barley, showing more efficiency of vetch to acquire nutrients from soil. Then, reducing vetch in mixture more than $50 \%$ caused a striking reduction in nutrient absorption (Table 4). The similar trend also was observed for crude protein. It can be concluded that barley could benefit from more suitable condition in second year, but hairy vetch showed more stability in nutrient absorption and protein production, with higher amounts in both years.

Many studies also have declared on advantages and economical aspects of mixed and inter-cropping than pure cropping, especially for forage production (Kundu and Chatterjee, 1981; Willey, 1981; Abbas et al., 2001). Osman and Osman (1982) studied mixtures of sorghum and a legume (Dolichos lablab L.) forage in the Sudan and observed that the highest yield was reached with 50:50 ratio of cereal-legume. Posler et al. (1993) evaluated compatibility of grass-legume mixture and stated almost all mixtures attained more yields than monocultures of grasses. Banik et al. (2006) performed an additive series experiment to study wheat-chickpea intercropping systems and concluded that total production and land use efficiency in intercropping treatments were higher than sole stands of both crops.

Crude protein content of produced forage is one of the most important criteria to measure forage quality (Assefa and Ledin, 2001). It is proven that legumes are richer in protein, whereas grasses have a higher carbohydrate content and their forage quality is too low to meet satisfactory production of many animal groups (Tompson et al., 1992). Therefore, concerning the relative low protein content of cereals (Mpairwe et al., 2002) and animal requirements for balanced feed, the importance of mixed cereal-legume cropping would be 
increasingly appear to supply a nutritional diet (Karadag, 2004; Lanyasunya et al., 2007). Similar to our results, Osman and Osman (1982) also found the highest and the lowest crude protein percentage in legume and cereal sole croppings, respectively and as legume ratio increased in mixture, protein percentage of mixture forage was improved. Posler et al. (1993) reported all legumes enhanced forage crude protein in mixture compared to cereals sole cropping, as also was observed by others in inter-and mixed cropping of different legume and grasses species (Abbas et al., 2001; Assefa and Ledin, 2001; Kuusela et al., 2006; Lithourgidis et al., 2006; Neumann et al., 2007; Mpairwe et al., 2002 Sehmidt and Tenpas, 1960).

Evaluation of dry forage yield and crude protein content using LER: Land Equivalent Ratio (LER) was used to assess profitability of mixtures relative to sole cropping of two crops in respect to dry forage and crude protein (Table 5). LERs of $>1$ were obtained in all mixed treatments, showing higher advantage and land use efficiency in mixed compared with sole cropping and the highest LERs for forage production and crude protein yield was obtained with 50:50 planting in both years (Table 5). These results again confirm that mixed cropping generally produce more yield per area than its related pure stands (Park et al., 2002). Marshall and Willey (1983) studied pearl millet-groundnut intercropping and found based on LER (1.28), when crops were intercropped, $28 \%$ more dry forage was produced relative to their sole cropping.

The replacement series curves indicated a higher actual forage yield of mixture than predicted yield (Fig. 2 and Table 6), again confirm mixed cropping advantage of these crops over their sole cropping. This additional yield can be attributed to reduction of whole competition as a result of declined interaspecies competition in related mixture. Indeed, differences in crops architecture and form can increase radiation penetration through canopy and therefore increase optimum plant density of mixture. In the second year, there was a reduction in actual yield of hairy vetch relative to expected yield at 25:75 (Vetch:Barley) planting ratio; however, barley could yielded more than expected, due to more favorable condition as discussed above. Therefore this increased barley yield could compensate vetch yield reduction, leading to higher forage yield in mixture than their sole cropping.

\section{CONCLUSION}

In general, this study showed a 50:50 mixture of barley-hairy vetch can gave the highest dry forage yield with maximal $\mathrm{N}, \mathrm{P}, \mathrm{K}$ and crude protein content, leading to higher LER and the highest forage quality and quantity than other planting ratio and sole cropping.

Results from these two-years mixed cropping studies indicated that mixed and inter-cropping of cereals with legumes can increase land productivity and forage production and enhance feed nutrient composition and minimize protein concentrate costs. Thus, using cereal-legume mixed crops, such as barley and hairy vetch can enhance dry season feed availability, leading to more sustainability of low-input and traditional agricultural systems, as well as modern and organic agroecosystems. Of course, screening for more suitable legumes is required to supply valuable forages in arid regions, as well as to gain other advantages from legumes, for example soil conservation and $\mathrm{N}$ fixation, with introducing them into the cropping systems of these areas.

\section{REFERENCES}

Abbas, M., M. Monib, A. Rammah, M. Fayez and N. Hegazi, 2001. Intercropping of sesbania (Sesbania sesban) and leucaena (Leucaena leucocephala) with five annual grasses under semi-arid conditions as affected by inoculation with specific rhizobia and associative diazotrophs. Agronomie, 21: 517-525. DOI: 10.1051/agro: 2001141

Arsalan, A. and F. Kurdali, 1996. Rainfed vetch-barley mixed cropping in the Syrian semi-arid conditions. II. Water use efficiency and root distribution. Plant Soil, 183: 149-160. DOI: 10.1007/BF02185574

Assefa, G. and I. Ledin, 2001. Effect of variety, soil type and fertilizer on the establishment, growth, forage yield, quality and voluntary intake by cattle of oats and vetches cultivated in pure stands and mixtures. Anim. Feed Sci. Technol., 92: 95-111. DOI: 10.1016/S0377-8401(01)00242-5

Banik, P., A. Midya, B.K. Sarkar and S.S. Ghose, 2006. Wheat and chickpea inter cropping systems in an additive series experiment: Advantages and weed smothering. Eur. J. Agron., 24: 326-332. DOI: 10.1016/j.eja.2005.10.010

Beets, W.C., 1982. Multiple Cropping and Tropical Farming Systems. Westview Press, Boulder, Colorado, ISBN: 0-566-00567-0, pp: 156.

Campbell, C.G., 1997. Grass pea (Lathyrus sativus L.). Promoting the Conservation and use of Underutilized and Neglected Crops. Institute of Plant Genetics and Crop Plant Research, Gatersleben/International Plant Genetic Resources Institute, Rome, Italy, pp: 91. http://www.bioversityinternational.org/fileadmin/bi oversity/publications/pdfs/430.pdf? cache $=1266662412$ 
Weil, R.R., 1988. Performance of Orchardgrass, Smooth Bromegrass, and Ryegrass in Binary Mixtures with Alfalfa. Agron. J., 80:509-512. http://agron.scijournals.org/cgi/reprint/80/3/509

Daniel, J., A. Phillips and B.K. Northup, 2006. Influence of summer management practices on grazed wheat pastures on run-off. Sediment and nutrient losses. Trans. ASAE., 49: 349-355. http://asae.frymulti.com/abstract.asp?aid $=20409 \& \mathrm{t}=1$

Franzluebbers, A.J., 2007. Integrated crop-livestock systems in the southeastern USA. Agron. J., 99: 349-355. DOI: 10.2134/agronj2006.0076

Ghosh, P.K., 2004. Growth, yield, competition and economics of groundnut/cereal fodder intercropping systems in the semi-arid tropics of India. Field Crops Res., 88: 227-237. DOI: 10.1016/j.fcr.2005.05.010

Gohl, B., 1981. Tropical feeds: Feed Information Summaries and Nutritive Values. 1st Edn., Animal Production and Health Series, FAO, Rome, ISBN: 9251004633, pp: 529.

Karadag, Y., 2004. Forge yields, seed yields and botanical compositions of some legume-barely mixtures under rain fed condition in semi-arid regions of Turkey. Asian J. Plant Sci., 3: 295-299. http://docsdrive.com/pdfs/ansinet/ajps/2004/295299.pdf

Kirschenmann, F.L., 2007. Potential for a new generation of biodiversity in agroecosystems of the future. Agron. J., 99: 373-376. DOI: 10.2134/agronj2006.0104

Kundu, B.C. and B.N. Chatterjee, 1981. Growth analysis of turmeric as a sole crop and in mixture with other crops. Indian J. Agric. Sci., 52: 584-589.

Kuusela, E., H. Klahili and P. Nykanen-Kurki, 2006. Fertilisation, seed mixtures and supplementary feeding for annual legume-grass-cereal pastures in organic milk production systems. Livest. Prod. Sci., 85: 113-127. DOI: 10.1016/S03016226(03)00139-8

Lanyasunya, Z.T.P., H.R. Wang, W.O. Ayako and D.M. Kuria, 2007. Effect of age at harvest and manure or fertilizer application on quality of Vicia villosa Roth. Agric. J., 2: 641-645. http://www.medwellonline.net/fulltext/aj/2007/641 -645.pdf

Lithourgidis, A.S., I.B. Vasilakoglou, K.V. Dhima, C.A. Dordas and M.D. Yiakoulaki, 2006. Forage yield and quality of common vetch mixtures with oat and triticale in two seedling ratios. Field Crops Res., 99: 106-113. DOI: 10.1016/j.fcr.2006.03.008

Marshall, B. and R.W. Willey, 1983. Radiation interception and growth in an intercrop of pearl millet/groundnut. Field Crops Res., 7: 141-160. DOI: 10.1016/0378-4290(83)90018-7
Mead, R. and R.W. Willey, 1980. The concept of land equivalent ratio and advantages in yields from intercropping. Exp. Agric., 16: 217-228. DOI: 10.1017/S0014479700010978

MeVay, K.A., D.E. Radeliffe and W.L. Hargrove, 1989. Winter legume effects on soil properties and nitrogen fertilizer requirements. Soil Sci., 53: 1856-1862. http://soil.scijournals.org/cgi/content/abstract/53/6/1856

Mpairwe, D.R., E.N. Sabiiti, N.N. Ummuna, A. Tegegne and P. Osuji, 2002. Effect of intercropping cereal crops with forage legumes and source of nutrients on cereal grain yield and fodder dry matter yield. Afr. Crop Sci. J., 10: 81-97 http://www.bioline.org.br/request?cs02008

Neumann, A., K. Schmidtke and R. Rauber, 2007. Effects of crop density and tillage system on grain yield and $\mathrm{N}$ uptake from soil and atmosphere of sole and intercropped pea and oat. Field Crops Res., 100: 285-293. DOI: 10.1016/j.fcr.2006.08.001

Osman, A.E and A.M. Osman, 1982. Performance of mixtures of cereal and legume forage under Irrigation in the Sudan. J. Agric. Sci. Camb., 98: 17-22. DOI:10.1017/S0021859600041058

Park, S.E., L.R. Benjamin, A.R. Watkinson, 2002. Comparing Biological productivity in cropping systems: A comparing Biological productivity in cropping systems: A competition approach. J. Applied Ecol., 39: 416-426. DOI: 10.1046/j.13652664.2002.00732.x

Pinkerton, B. and F. Pinkerton, 2002. Managing Forage for Meat Goats. In: Meat Goat Production Handbook, Extension Service. Collage of Agriculture, Forestry and Life Sciences. Clemson University, USA.

Posler, G.L., A.W. Lenssen and G.L. Fine, 1993. Forage yield, quality compatibility and persistence of warm-season grass-legume mixture. Agron. J., 85: 554-560.

http://agron.scijournals.org/cgi/content/abstract/85/ $3 / 554$

Prasad, N.K., R.K. Bhagat, A.P. Singh and R.S. Singh, 1990. Intercropping of deenanath grass (Pennisetum pedicellatum) with cowpea (Vigna unguiculata) for forage production. Indian J. Agric. Sci., 60: 115-118. http://www.cababstractsplus.org/abstracts/Abstract. aspx?AcNo=19910742508

Rao, S.C., B.K. Northup and H.S. Mayeux, 2005. Candidate cool season legumes for filling forage deficit periods in the southern Great Plains. Crop Sci., 45: 1973-1977. http://crop.scijournals.org/cgi/content/abstract/45/5 12068 
Reddy, M.S. and R.W. Willey, 1981. Growth and resource use studies in an inter crop of pearl millet/groundnut. Field Crops Res., 4: 13-24. DOI: 10.1016/0378-4290(81)90050-2

Sehmidt, D.R. and G.H. Tenpas, 1960. Seasonal response of grasses fertilized with nitrogen compared to legume-grass mixture. Agron. J., 57: 428-431.

http://agron.scijournals.org/cgi/reprint/57/5/428

Tompson, D.J., D.G. Stout and T. Moore, 1992. Forage production by four annual cropping sequences emphasizing barley irrigation in southern interior British Columbia. Can. J. Plant Sci., 72: 181-185. DOI: $10.4141 /$ cjps92-018

Walling, I., W. vanVark, V.J.G. Houba and J.J. Vander Lee, 1989. Soil and Plant Analysis, a series of syllabi. Part 7. Plant Analysis Procedures. 1st Edn., Wageningen Agriculture University, pp: 263.

Willey, R.W., 1981. A scientific approach to intercropping research. Proceedings of International Workshop on Intercropping, Jan. 1013, International Crops Research Institute for the Semi-Arid Tropics (ICRISAT) Publication, Andhra Pradesh, India, Heydarabad, India, pp: 4-14. http://dspace.icrisat.ac.in/dspace/handle/123456789 $/ 1234$
Yau, S.K., J. Ryan, M. Pala, M. Nimah and A. Nassar, 2004. Common vetch in rotation with barely: A sustainable farming system for a cool, semi-arid Mediterranean area. Proceedings of the 4th international Crop Science Congress, Sept. 26-Oct. 1, Brisbane, Australia, pp: 1-1. http://www.cropscience.org.au/icsc2004/poster/2/1/ 2/589_yausk.htm

Zougmore, R., F. Nagumo and A. Hosikawa, 2006. Nutrient uptakes and maize productivity as affected by tillage system and cover crops in a subtropical climate at Ishigaki, Okinawa, Japan. Soil Sci. Plant Nutr., 52: 509-518. 